\title{
Effect of cyclosporin A on proteinuria in the course of glomerulopathy associated with WT1 mutations
}

\author{
Anna Maria Wasilewska • \\ Elżbieta Kuroczycka-Saniutycz • \\ Walentyna Zoch-Zwierz
}

Received: 28 June 2010 / Accepted: 11 August 2010/Published online: 17 September 2010

(C) The Author(s) 2010. This article is published with open access at Springerlink.com

\begin{abstract}
Denys-Drash syndrome (DDS) is characterized by progressive glomerulopathy caused by diffuse mesangial sclerosis (DMS), genitourinary defects, and a higher risk of developing Wilms' tumor. It is commonly assumed that the DMS is unresponsive to any medications. In this report, we present a patient with Denys-Drash syndrome, in whom the cyclosporine A (CsA) was found to induce total remission. This observation and observations of other authors confirm that in genetic forms of nephrotic syndrome, the proteinuric effect of CsA may be due to a non-immunologic mechanism. We confirm the beneficial effect of CsA treatment in DDS; however, the potential nephrotoxicity of this drug will probably not allow long-term use.
\end{abstract}

Keywords Denys-Drash syndrome $\cdot$ Cyclosporine A

\section{Introduction}

Nephrotic syndrome in the first year of life in two thirds of cases is caused by mutations in four genes (NPHS1, NPHS2, WT1, and LAMB2) [10]. The Wilms' tumor suppressor gene 1 (WT1) encodes a transcription factor involved in kidney and gonadal development [19]. Heterozygous de novo mutations in WT1 gene cause Denys-Drash syndrome (DDS) and Frasier syndrome (FS), two syndromes charac-

A. M. Wasilewska $(\square) \cdot$ E. Kuroczycka-Saniutycz $\cdot$

W. Zoch-Zwierz

Department of Paediatrics and Nephrology,

Medical University of Białystok,

ul. Waszyngtona 17,

15-274 Białystok, Poland

e-mail: annwasil@interia.pl terized by nephrotic syndrome (NS) with either diffuse mesangial sclerosis (DMS) in DDS or focal segmental glomerulosclerosis (FSGS) in FS, genitourinary defects and a higher risk of developing Wilms' tumor in DDS, or gonadal dysgerminoma in both DDS and FS [13].

Gellermann et al. [8] recently published three children with FSGS on renal biopsy and WT1 mutations, who responded to intensified therapy consisting of oral cyclosporine A (CsA) in combination with oral or intravenous glucocorticoids. CsA has been used in the treatment of idiopathic syndrome for 20 years [14]. The mechanism of CsA action in minimal change disease was the inhibition of nuclear factor of activated T cell (NFAT) signaling in $\mathrm{T}$ lymphocytes [15]. However, the therapeutic effect of CsA in genetic nephrotic syndrome is probably related to a direct influence of CsA on podocytes.

In this report, we present a patient with Denys-Drash syndrome, in whom the calcineurin inhibitors were found to induce total remission.

\section{Case report}

Our patient is the first child of non-consanguineous young parents (mother 32, father 34 years) without any past medical history of kidney diseases. The pregnancy was uneventful. The infant was born at 41 weeks' gestation (birth weight $3,450 \mathrm{~g}$, length $55 \mathrm{~cm}$ ). The delivery and neonatal period were normal. At the age of 7 months, she was hospitalized for the first time in the Pediatric Nephrology Department because of proteinuria and hematuria, which was found in routine urinalysis performed before the vaccination. 
On admission, the girl was in good general condition. Physical examination revealed no edema, normal female external genitalia, and normal body weight and height for chronological age. Blood pressure was $93 / 49 \mathrm{mmHg}$ and pulse was 120 beats per minute.

Initial laboratory investigations revealed variable nonselective proteinuria $200-960 \mathrm{mg} / \mathrm{dl}$ in morning sample, protein/creatinine ratio $27 \mathrm{~g} / \mathrm{g}$, hypoproteinemia $(4.79 \mathrm{~g} / \mathrm{dl})$, hypoalbuminemia $(3.0 \mathrm{~g} / \mathrm{dl})$, hypercholesterolemia $(299 \mathrm{mg} / \mathrm{dl})$, thrombocytosis $\left(567 \times 10^{3} / \mu \mathrm{l}\right)$, and reduced levels of $\operatorname{IgG}$ and $\operatorname{IgA}$.

The serum creatinine level was $0.23 \mathrm{mg} / \mathrm{dl}$, urea was $8 \mathrm{mg} / \mathrm{dl}$, and the glomerular filtration rate was $133 \mathrm{ml} / \mathrm{min} /$ $1.73 \mathrm{~m}^{2}$ by the Schwartz formula. Antinuclear antibodies were negative, and the level of $\mathrm{C} 3$ and $\mathrm{C} 4$ were within normal limits. Congenital nephrotic syndrome was suspected. The ultrasound of the kidneys showed inhomogeneous parenchymal hyperechogenicity. Any image consistent with renal tumor was not seen.

Chromosomal analysis demonstrated karyotype 46, XX, and the biopsy of the kidney demonstrated diffuse mesangial proliferation and diffuse fibrillar increase, what may represent early stage of diffuse mesangial sclerosis. The glomerular lesions contained high amount of fibrils in the mesangial matrix with diffuse mesangial proliferation. The capillary walls were covered with hypertrophied podocytes. The glomerular basement membranes were thickened. A few tubules showed microcystic dilatation. Few pseudotubular structures in endothelial cells were found. Immunofluorescence on frozen sections using rabbit polyclonal antisera against human $\operatorname{IgG}$, $\operatorname{IgA}$, IgM, and $\mathrm{C} 3$ revealed only weak segmental IgM staining.

The molecular genetic analysis was performed in the laboratory at the University of Michigan in the USA. Mutation analysis of exons 8 to 9 of WT1 was performed, and the mutation R394W (c. $1180 \mathrm{C}>\mathrm{T}$ ) was found in our patient. No WT1 gene mutations were found in the parents of the affected child.

The treatment with enalapril $(1.25 \mathrm{mg} /$ day $)$, which was started after the admission and was continued for 11 months, did not change the proteinuria significantly. There was no reduction in proteinuria after 4-week oral prednisone treatment $\left(60 \mathrm{mg} / \mathrm{m}^{2} /\right.$ day $)$. Seven months later, we started the therapy with CsA $(6 \mathrm{mg} / \mathrm{kg} / 24 \mathrm{~h}$ in two divided doses). After 2 months of CsA treatment, partial remission was observed. The serum albumin level rose and proteinuria declined. The pre-dose/trough (C0) CsA level was $104.4 \mathrm{ng} / \mathrm{ml}$. After 6 months of CsA treatment, complete remission was achieved. There was no proteinuria. The serum total protein was $(6.47 \mathrm{mg} / \mathrm{dl})$, albumin $(4.26 \mathrm{mg} / \mathrm{dl})$, cholesterol $197 \mathrm{mg} / \mathrm{dl}$, and platelet count $385 \times 10^{3} / \mathrm{ql}$. Creatinine level was $0.32 \mathrm{mg} / \mathrm{dl}$ and the glomerular filtration rate was $147 \mathrm{ml} / \mathrm{min} / 1.73 \mathrm{~m}^{2}$. The pre-dose/trough (C0) CsA level was $95.03 \mathrm{ng} / \mathrm{ml}$.
At the 6 month of the treatment, we decided for CsA dose reduction to $4.5 \mathrm{mg} / \mathrm{kg}$, but a month later, slight proteinuria was observed. Now CsA treatment is continued with the higher dose $(6 \mathrm{mg} / \mathrm{kg} / 24 \mathrm{~h})$. The patient is under the regular control of The Pediatric Nephrology Department. She has no proteinuria. Serum creatinine level is normal. The ultrasonography examination, performed every 3 months, has not revealed any signs of tumor. A control kidney biopsy is planned soon.

\section{Discussion}

We report the benefits of CsA treatment of the patient with glomerulopathy associated with WT1 mutation as seen in Denys-Drash syndrome. The girl in this report had earlyonset SRNS secondary to DMS, what was confirmed in kidney biopsy. Genetic studies showed mutations in intron 9 of WT1 gene c. $1180 \mathrm{C}>\mathrm{T}$. This is the most common mutation found in DDS [8]. Mutations in exons 8 and 9 of the WT1 gene have been found in patients with isolated SRNS and in SRNS associated with Wilms' tumor or urogenital malformations. The data presented by Mucha et al. [16] indicated that screening of WT1 exons 8 and 9 in patients with sporadic SRNS is sufficient to detect pathogenic WT1 mutations. Our patient lacked any evidence of anomaly of the kidney or urogenital tract. No renal tumor has not been seen so far. It is possible that our patients have an incomplete form of DDS; however, it corresponds to the observation of Ismaili et al. [11], who reported the presence of Wilms' tumor in only one of two patients with DDS. Chernin et al. [5] in the recent publication suggested that missense mutations can occur with and without Wilms' tumor.

In our patient, the diagnosis of DDS was done in the eighth month of life. The girl fulfilled the criteria of SRNS. In this situation, CsA therapy was started with a significant reduction of proteinuria and remission of nephrotic syndrome. Three months later, complete remission of proteinuria was found.

Whereas genetic forms of nephrotic syndrome do not respond to therapy with immunosuppressive drugs, partial remission has been reported following therapy with calcineurin inhibitors in patients with NPHS2 [12], Frasier syndrome [8], mutations of the phospholipase C epsilon gene (PLCE1) [9], and Alport syndrome [3, 4]. Gellermann et al. [8] reported three children with FSGS associated with WT1 mutation treated with combined CsA and prednisone therapy given for 6 and 12 months. In long-term observation, the authors observed remission of NS and significant reduction of proteinuria. Our patient was treated with CsA alone and we observed complete remission of proteinuria. This is interesting because it was considered that DMS was unresponsive to any medications [20]. 
The therapy does not seem to be accompanied by a significant loss of renal function on the short term. We plan to continue the treatment with the lowest possible dose which controls the proteinuria. A control kidney biopsy to check for CsA nephrotoxicity will be done soon.

Calcineurin is a ubiquitously expressed serine/threonine phosphatase [1]. It was considered that the main effect of CsA treatment in nephrotic syndrome caused by $\mathrm{T}$ cell dysfunction was the inhibition of NFAT signaling in T cells [6]. However, it was found that CsA can also reduce proteinuria in non-immunological diseases, raising doubts about the above hypothesis. In genetic diseases, mechanisms other than the immunosuppressive effects are involved in reduction of proteinuria. Similarly, the afferent arteriole vasoconstriction, which is induced by CsA, does not seem to play the main role in the reduction of proteinuria. This fact was suggested by Zietse et al. [21], who studied the influence of CsA on proteinuria in different glomerulopathies and found the reduction of protein excretion in minimal change disease, but not in membranoproliferative glomerulonephritis or FSGS. The possible mechanism in genetic NS may be that proposed by Faul et al. [7]. The authors suggested the influence of CsA on synaptopodin, an actin binding protein that was highly expressed in podocytes. It is also an important regulator of podocyte function through its interaction with CD2AP [2]. It was shown that calcineurin caused the dephosphorylation of synaptopodin and caused proteinuria via its degradation. In this situation, CsA therapy leads to the stabilization of its actin cytoskeleton. This mechanism seems to be possible because significant reduction $(30 \%)$ of CsA dose caused the slight proteinuria in our patient, so we increased the dose to initial one. Our observation seems to confirm the theory of Mundel and Reiser, who suggested that proteinuria is due to an enzymatic disease of the podocytes [18]. It is likely that podocytes are a direct target of CsA, which preserves the phosphorylation-dependent synaptopodin-14-3-3beta interaction, protects synaptopodin from degradation, and preserves a stable filtration barrier [7, 17].

The fact that the antiproteinuric effect of CsA results from a direct effect on podocytes explains not only its beneficial role in most steroid-resistant and steroid-dependent nephrotic syndromes but also the fact of cyclosporine dependency. Our observation and observations of other authors [3, 4, 9, 12, 15] confirm the beneficial effect of CsA treatment in genetic NS; however, the potential nephrotoxicity of this drug will probably not allow the long-term use.

Acknowledgments We wish to thank Prof. Friedhelm Hildebrandt (University of Michigan) for performing the WT1 mutation screening in our patient.

Conflict of interest statement The authors declare that they have no conflict of interest.
Open Access This article is distributed under the terms of the Creative Commons Attribution Noncommercial License which permits any noncommercial use, distribution, and reproduction in any medium, provided the original author(s) and source are credited.

\section{References}

1. Aramburu J, Heitman J, Crabtree G (2004) Calcineurin: a central controller of signalling in eukaryotes. EMBO Rep 5:343-348

2. Bensman A, Niaudet P (2010) Non-immunologic mechanisms of calcineurin inhibitors explain its antiproteinuric effects in genetic glomerulopathies. Pediatr Nephrol 25:1197-1199

3. Callis L, Vila A, Nieto J, Fortuny G (1992) Effect of cyclosporin A on proteinuria in patients with Alport's syndrome. Pediatr Nephrol 6:140-144

4. Callis L, Vila A, Carrera M, Nieto J (1999) Long-term effects of cyclosporine A in Alport's syndrome. Kidney Int 55:1051-1056

5. Chernin G, Vega-Warner V, Schoeb D, et al. (2010) Genotype/ phenotype correlation in nephrotic syndrome caused by WT1 mutations. Clin J Am Soc Nephrol doi:10.2215/CJN.09351209

6. Crabtree G, Olson E (2002) NFAT signaling: choreographing the social lives of cells. Cell 109 (Suppl):S67-S79

7. Faul C, Donnelly M, Merscher-Gomez S et al (2008) The actin cytoskeleton of kidney podocytes is a direct target of the antiproteinuric effect of cyclosporine A. Nat Med 14:931-938

8. Gellermann J, Stefanidis C, Mitsioni A, Querfeld U (2010) Successful treatment of steroid-resistant nephrotic syndrome associated with WT1 mutations. Pediatr Nephrol 25:1285-1289

9. Hinkes B, Wiggins R, Gbadegesin R et al (2006) Positional cloning uncovers mutations in PLCE1 responsible for a nephrotic syndrome variant that may be reversible. Nat Genet 38:1397-1405

10. Hinkes B, Mucha B, Vlangos C et al (2007) Nephrotic syndrome in the first year of life: two thirds of cases are caused by mutations in 4 genes (NPHS1, NPHS2, WT1, and LAMB2). Pediatrics 119: e907-e919

11. Ismaili K, Verdure V, Vandenhoute K et al (2008) WT1 gene mutations in three girls with nephrotic syndrome. Eur J Pediatr 167:579-581

12. Malina M, Cinek O, Janda J, Seeman T (2009) Partial remission with cyclosporine $\mathrm{A}$ in a patient with nephrotic syndrome due to NPHS2 mutation. Pediatr Nephrol 24:2051-2053

13. McTaggart S, Algar E, Chow C et al (2001) Clinical spectrum of Denys-Drash and Frasier syndrome. Pediatr Nephrol $16: 335-339$

14. Meyrier A (1989) Treatment of glomerular disease with cyclosporin A. Nephrol Dial Transplant 4:923-931

15. Meyrier A (2009) Treatment of focal segmental glomerulosclerosis with immunophilin modulation: when did we stop thinking about pathogenesis? Kidney Int 76:487-491

16. Mucha B, Ozaltin F, Hinkes B et al (2006) Mutations in the Wilms' tumor 1 gene cause isolated steroid resistant nephrotic syndrome and occur in exons 8 and 9. Pediatr Res 59:325-331

17. Mundel P, Kriz W (1995) Structure and function of podocytes: an update. Anat Embryol (Berl) 192:385-397

18. Mundel P, Reiser J (2010) Proteinuria: an enzymatic disease of the podocyte? Kidney Int 77:571-580

19. Niaudet P, Gubler M (2006) WT1 and glomerular diseases. Pediatr Nephrol 21:1653-1660

20. Schumacher V, Scharer K, Wuhl E et al (1998) Spectrum of early onset nephrotic syndrome associated with WT1 missense mutations. Kidney Int 53:1594-1600

21. Zietse R, Wenting G, Kramer P et al (1992) Effects of cyclosporin A on glomerular barrier function in the nephrotic syndrome. Clin Sci (Lond) 82:641-650 